\title{
Subject Librarians: Engaging with the Learning and Teaching Environment edited by Penny Dale, Matt Holland and Marian Matthews 2006, Aldershot: Ashgate, xix + 199pp, £50.00, ISBN 0754640957
}

The stated intention of this book on subject librarianship is to fill a perceived gap in the literature, provide 'snapshots' of subject librarians' work and encourage discussion on how the role is developing. Target audiences include 'other student support services' and students of library and information science, in addition to practicing librarians. The 15 chapter contributors are mainly current or former subject/liaison librarians, but include several professionals who have moved into library management or academic administration and one former academic now working in educational development. Despite claims to a breadth of perspectives, the experiences reflected are predominantly - though not exclusively - those of practitioners in post-1992 UK universities, notably Bournemouth and Greenwich.

Thirteen chapters are arranged in four somewhat unbalanced sections. Part I, 'The subject specialist in higher education', has seven contributions covering the literature of the field, professional engagement, quality assurance and enhancement, learning and teaching, relating to further education, virtual learning environments, changing relationships in the university. Part II, 'Serving different constituencies', has four chapters, dealing in turn with undergraduates, asynchronous learners, researchers and international students. Part III, 'International perspectives', consists of a single chapter, among the shortest in the volume, but with much the longest title: 'A review of international trends in library faculty support in higher education: a special focus on Southern African university libraries'. Part IV contains only a rather brief conclusion.

Subject librarians (also known by various other titles, such as liaison librarian, information specialist, learning adviser and, particularly in the United States, reference librarian) have long played a pivotal role in academic libraries. Their contribution was seen as highly significant in the Fielden Report, part of the seminal Follett review of UK academic libraries (John Fielden Consultancy, 1993; Joint Funding Councils' Libraries Review Group, 1993), but it has been subject to frequent challenge in recent cash-strapped times, making the survival of the species and its continuing evolution a topic undoubtedly deserving the level of treatment that this type of publication should be able to provide. Unfortunately, as is often the case with multiauthored works, the breadth of coverage, depth of treatment and quality of writing of the different chapters vary enormously, resulting in a frustratingly varied set of contributions, which range from the disappointingly mediocre to the truly outstanding.

The opening literature review is clearly structured and identifies several relevant themes, but it concentrates on the UK, which accounts for only a minority of published comments on the subject. It thus fails to locate British practice effectively in its global context, ignores US discussion of the concept of 'information consulting' and neglects interesting Australian deliberations on faculty-librarian collaboration - collaborative working in this chapter is interpreted primarily as working with counterparts in other libraries. The chapter on international trends contains a short literature review that partly compensates for this unduly narrow focus, but again it largely excludes US literature, with the main focus being on Australia, Asia and Africa. It also suggests that the United States pioneered the concept of subject librarianship in the 1970s, which is somewhat confusing when set alongside the discussion in Chapter 1 of UK developments in the early part of the 20th century. 
Chapter 2 provides a well-documented discussion of various aspects of subject librarian activity, highlighting the importance of Continuing Professional Development in remaining effective in the role. Chapter 3 traces the development of quality assurance and enhancement in UK higher education since 1993, drawing on experience at Bournemouth University to show how libraries can benefit from engagement with such processes, and arguing (quite reasonably) that the principles established are still valid, even though procedures are changing.

Also worth noting is Kerry Shephard's overview of learning and teaching developments (Chapter 4) and his discussion (in Chapter 7, co-authored with Marian Matthews) of changing roles and relationships arising from these developments. Shephard takes us beyond the librarian's perspective to the view of an academic educational developer, but one who has evidently worked with information professionals in areas such as e-learning and widening participation. He opens refreshingly by challenging the received view of the Dearing Report's significance as a change agent (National Committee of Inquiry into Higher Education, 1997), seeing it instead as another mile- stone in a journey stretching back over several decades.

The theme of widening participation is the main focus of Chapter 5, where Jane Ryland draws effectively on her specialist expertise in managing library partner- ships across the higherfurther education boundary to explain problems typically encountered and how to over- come them. In contrast, Chapter 6, supposedly on virtual learning environments (VLEs), is a fragmented collection of observations on technology-related developments, lacking any real coherence or focus. The author here fails to explain her interpretation of the VLE concept and the nature of the subject librarian contribution to the various projects described is far from clear.

In Part II, Matt Holland's well-referenced chapter on supporting researchers provides an excellent survey of key trends and developments in the UK academic research landscape, identifying many relevant reviews, reports, policy statements and service initiatives. The only important omissions here are the UK Government's major programme in e-science and the more bottom-up 'open access' movement, both of which have significant implications for the role of the subject librarian. The focus here is mainly on research students and service provision, with minimal attention given to collection management, which in this context often now includes managing research datasets and developing institutional repositories.

The most impressive contribution to the book is Frank Trew's superb evaluation and synthesis of the literature on library support for international students, which cites 57 items and is arranged thematically to cover key issues such as linguistic and cultural barriers, reference and information services, library induction and information literacy instruction, staff and collection development, concluding with an identification of areas for further research. Comments on the literature are interspersed with insights from the author's extensive experience in serving this constituency at the American International University in London. The remaining chapters are slightly disappointing, offering some interesting examples of service development, but not quite getting the level of focus needed on the subject librarian's work and role.

Overall, this book is a welcome addition to the library literature, despite the shortcomings identified. An additional irritant, all the more so in view of the price tag, is the extraordinarily high number of typographical errors, suggesting a very casual approach to proof-reading. As the sub-title indicates, the emphasis is on learning and teaching support, with the focus on the UK scene (apart from a brief excursion to Southern Africa). The book will be of most value to librarianship students and practitioners new to this role or approaching specific aspects for the first time, but the chapters by Holland and Trew offer useful reviews for seasoned professionals too. 
Accepted version $\quad$ Published in Journal of Librarianship and Information Science, 40 (3).

\section{References}

John Fielden Consultancy (1993) Supporting Expansion: A Report on Human Resource Management in Academic Libraries for the Joint Funding Councils' Libraries Review Group. Bristol: Higher Education Funding Council for England.

Joint Funding Councils' Libraries Review Group (1993) Report. Bristol: Higher Education Funding Council for England.

National Committee of Inquiry into Higher Education (1997) Higher Education in the Learning Society. Norwich: HMSO.

Sheila Corrall

Department of Information Studies

University of Sheffield 